\title{
Se Alleviated Oxidative Stress-Mediated Complex Poisoning Mechanism in Pb-Treated Chicken Kidneys: Inflammation, Heat Shock Response, and Autophagy
}

\section{Zhiying Miao}

Northeast Agricultural University

Weikang Yu

Northeast Agricultural University

Yueyang Wang

Fourth Affiliated Hospital of Harbin Medical University

Xianhong Gu

State Key Laboratory of Animal Nutrition

Xiaohua Teng ( $\nabla$ tengxiaohuaneau@163.com )

Northeast Agricultural University https://orcid.org/0000-0002-1061-2751

\section{Research}

Keywords: Lead, Selenium, Oxidative stress, Inflammation, Heat shock protein, Autophagy

Posted Date: January 15th, 2021

DOI: https://doi.org/10.21203/rs.3.rs-146251/v1

License: (c) (1) This work is licensed under a Creative Commons Attribution 4.0 International License.

Read Full License 


\section{Abstract}

Background: Lead $(\mathrm{Pb})$ is a toxic environmental pollutant and can exerts toxicity in kidneys. It is known that selenium (Se) has an antagonistic effect on $\mathrm{Pb}$ poisoning. However, biological events during the process were not well understood in chicken kidneys.

Methods: One hundred and eighty male Hyline chickens (7-day-old) were randomly divided into the control group (offering standard diet and potable water), the Se group (offering $\mathrm{Na}_{2} \mathrm{SeO}_{3}$-added standard diet and potable water), the $\mathrm{Pb}$ group (offering standard diet and $\left(\mathrm{CH}_{3} \mathrm{OO}\right)_{2} \mathrm{~Pb}$-added potable water), and the $\mathrm{Pb}+\mathrm{Se}$ group (offering $\mathrm{Na}_{2} \mathrm{SeO}_{3}$-added standard diet and $\left(\mathrm{CH}_{3} \mathrm{OO}\right)_{2} \mathrm{~Pb}$-added potable water). On $30^{\text {th }}$, $60^{\text {th }}$, and $90^{\text {th }}$ days, kidneys were removed to perform the studies of histological structure, oxidative stress indicators, cytokines, heat shock proteins, and autophagy in the chicken kidneys.

Results: The experimental results indicated that $\mathrm{Pb}$ poisoning changed renal histological structure; decreased catalase, glutathione-s-transferase, and total antioxidative capacity activities; increased hydrogen peroxide content; induced mRNA and protein expression of heat shock proteins; inhibited interleukin (IL)-2 mRNA expression, and induced IL-4 and IL-12 $\beta$ mRNA expression; inhibited mammalian target of rapamycin mRNA and protein expression, and induced autophagy-related gene mRNA and protein expression in the chicken kidneys. Supplement of Se mitigated the above changes caused by $\mathrm{Pb}$.

Conclusion: Our research strengthens the evidence that $\mathrm{Pb}$ induced oxidative stress, inflammation, heat shock response, and autophagy and Se administration alleviated $\mathrm{Pb}$ poisoning through mitigating oxidative stress in the chicken kidneys.

\section{Background}

Lead $(\mathrm{Pb})$ is a well-known toxic environmental pollutant. Although measure has been taken to control $\mathrm{Pb}$ pollution, $\mathrm{Pb}$ poisoning is still an important health issue in many countries [1]. Continuous exposure of human beings and animals to this metal can induce health problems, and even lead to death [2]. Sancar (2019) found that the children exposure to Pb born between 1972 and 1973 in Dunedin, New Zealand may affect mental health in adulthood [3]. Exposure to $\mathrm{Pb}$, even at low levels, was associated with chronic kidney disease in adults of UK [4]. Pb pollution led to millions of bird death every year around the world [5] and even drove California condors (an endangered species) to the edge of extinction from 1997 to 2010 [6].

Oxidative stress caused by prooxidant/antioxidant imbalance with reactive oxygen species overproduction plays a crucial role in renal injury, as it has been considered a central aggravating factor [7]. There are cross-talk between oxidative stress and inflammation in preeclampsia [8]. Heat shock proteins (HSPs) are a family of proteins produced by cells in response to exposure to stressful conditions and are primary mitigators of cell stress [9]. Autophagy occurs at basal levels to preserve cellular homeostasis by recycling proteins and organelles which can also act in response to oxidative stress [10]. 
Oxidative stress, inflammation, heat shock response, and autophagy have been described in many studies as prominent factors in mediating many pathological alterations in response to toxic agents [11]. $\mathrm{Pb}$ induced oxidative stress which led to autophagy in the spleens of chickens [12] and mice [13]. Ge et al. (2018) reported that autophagy was intertwined with inflammation, and cytokines can help mediate this interaction [14]. Autophagy was decreased in nude mice with hepatocellular carcinoma and was inversely correlated with HSPs expression [15]. However, it is not well characterized whether there is an interplay between these factors or any combination of them in mediating harmful mechanisms of pathological alterations in Pb-treated kidneys.

Selenium (Se) is a necessary trace element for organisms [16]. As an antioxidant, it helps in maintaining intracellular redox balance. Our previous study found that $\mathrm{Se}$ could alleviate $\mathrm{Pb}$-caused oxidative stress [17], heat shock response [18], and inflammatory damage [19] in chicken testes. In addition, recent studies reported that Se-yeast inhibited the initiation of autophagy and enhanced autophagic clearance in the brains of Alzheimer's disease mice [20]. Although antagonistic effect of Se on $\mathrm{Pb}$ was investigated, underlying molecular mechanism remained to be elucidated. Therefore, in current study, we designed interaction model of $\mathrm{Pb}$ and $\mathrm{Se}$ in chickens and detected histological alterations, oxidative stress indexes, mRNA and protein expression of interleukins, HSPs, and autophagy-related genes to reveal antagonistic mechanism of $\mathrm{Se}$ on $\mathrm{Pb}$ in the chicken kidneys.

\section{Methods}

\section{Animals}

Hyline chickens (1-day-old) were provided standard diet (containing $0.49 \mathrm{mg} / \mathrm{kg} \mathrm{Se}$ ) (D) and potable water (W) during 7 days acclimatization. Then, 180 healthy birds were randomly divided into four groups with 45 numbers: the control group (I group), the Se group (II group), the $\mathrm{Pb}$ group ( $₫$ group), and the $\mathrm{Pb}+$ Se group ( $\nabla$ group), respectively. I group was given $D$ and $W$; II group received a diet enriched with $\mathrm{Na}_{2} \mathrm{SeO}_{3}$-added D (containing $1 \mathrm{mg} / \mathrm{kg} \mathrm{Se}$ ) (SeD) and W; III was group offered $\left(\mathrm{CH}_{3} \mathrm{OO}\right)_{2} \mathrm{~Pb}$ through drinking water (containing $350 \mathrm{mg} / \mathrm{L} \mathrm{Pb}$ ) (PbW), following median lethal dose of $\mathrm{Pb}$ acetate for cocks and the need of chicken experiment in toxicology [21]; and $₫$ grwas supplied with $\mathrm{SeD}$ and PbW. $\mathrm{Na}_{2} \mathrm{SeO}_{3}$ and $\left(\mathrm{CH}_{3} \mathrm{OO}\right)_{2} \mathrm{~Pb}$ were analytical reagent grade and were purchased from Tianjinzhiyuan Chemical Reagen Co., Ltd. Tianjin, China. According to feeding standard, the chickens were provided food and water ad libitum at a temperature of $22 \pm 2{ }^{\circ} \mathrm{C}$ under $12 \mathrm{~h}$-light/ $12 \mathrm{~h}$-dark cycles in Laboratory Animal Center, Animal Medical College, Northeast Agricultural University (Harbin, China) until the end of experiment.

\section{Tissue collection}

On 30th, 60th, and 90th days of the experiment, respectively, 15 birds with $12 \mathrm{~h}$ fasting from each group were euthanized. Then the kidneys were immediately separated and cleaned with ice-cold saline. The first part of the sample was immediately frozen in liquid nitrogen and stored at $-80{ }^{\circ} \mathrm{C}$ to detect mRNA and 
protein expression. The second part of the sample was homogenized to determine oxidative stress indexes. The third part of the sample was fixed in $4 \%$ paraformaldehyde solution and stayed at least $24 \mathrm{~h}$ to perform microstructure observation. The last part of the sample was fixed in $2.5 \%$ glutaraldehyde phosphate buffer saline to observe ultrastructure.

\section{Histological analyses}

Preparation of sections described in our present papers was processed as previously described [22]. Briefly, the kidney tissues fixed with paraformaldehyde solution were dehydrated in gradient alcohol (30, $50,70,90,100$, and $100 \%$ ), were embedded in paraffin, and were sectioned to nominal thicknesses of $4 \mu \mathrm{m}$. The sections were stained with hematoxylin and eosin. Finally, the sections were subjected to microscopic examination (Eclipse 80i, Nikon, Tokyo, Japan) and photographs were taken.

The samples were cut into blocks with the size of $1.0 \times 1.0 \times 1.0 \mathrm{~mm}$ and were immediately fixed in $2.5 \%$ glutaraldehyde phosphate buffer saline at $4^{\circ} \mathrm{C}$ for $3 \mathrm{~h}(\mathrm{pH} 7.2)$. The blocks were rinsed in $0.1 \mathrm{~mol} / \mathrm{L} \mathrm{PBS}$, put in $1 \%$ osmium tetroxide at $4{ }^{\circ} \mathrm{C}$ for $1 \mathrm{~h}$, and were rinsed in $0.1 \mathrm{~mol} / \mathrm{L}$ PBS again. The tissues were impregnated and were embedded with epoxy resins. The obtained sections were counterstained with uranyl acetate and lead citrate after ultrathin section. The ultrastructure of chicken kidneys was observed and was photographed using transmission electron microscope (Model JEM-1200EX, Jeol Jem, Japan).

\section{Oxidative stress indexes}

Kidney tissues were pulverized in a homogenization buffer $\left(0.32 \mathrm{M}\left(\mathrm{NH}_{4}\right)_{2} \mathrm{SO}_{4}, 0.10 \mathrm{mM}\right.$ EDTA, $25 \%$ glycerol, and $0.05 \mathrm{M}$ Tris-HCl pH 7.9). Obtained sample was homogenized on ice using a homogenizer. The homogenate solution was centrifuged at $16,000 \mathrm{~g}$ and $4^{\circ} \mathrm{C}$ for $5 \mathrm{~min}$. Obtained supernatant was used for determining T-AOC, GST, and CAT activities and $\mathrm{H}_{2} \mathrm{O}_{2}$ content in chicken kidneys using kits produced by Nanjing Jiancheng Bioengineering Institute (Nanjing, China) following the manufacturer's instructions. All samples were detected in duplicate in a single assay to avoid interassay variation.

\section{Relative mRNA expression analysis}

Primer sequence and Genbank accession numbers of detected genes were listed in Table 1.

Table 1. GAPDH served as internal reference gene. The special primers were synthesized by Invitrogen Biotechnology Co. Ltd. in Shanghai, China. 
Table 1

Special primers of genes used for real-time PCR

\begin{tabular}{|c|c|c|c|}
\hline $\begin{array}{l}\text { Gene } \\
\text { name }\end{array}$ & $\begin{array}{l}\text { Accession } \\
\text { number }\end{array}$ & Primer sequence & $\begin{array}{l}\text { Size of the } \\
\text { products (bp) }\end{array}$ \\
\hline \multirow[t]{2}{*}{$\mathrm{IL}-2$} & \multirow[t]{2}{*}{ AY510091 } & $\begin{array}{l}\text { Forward 5'- } \\
\text { GAACCTCAAGAGTCTTACGGGTCTA - 3' }\end{array}$ & \multirow[t]{2}{*}{111} \\
\hline & & $\begin{array}{l}\text { Reverse 5'- } \\
\text { ACAAAGTTGGTCAGTTCATGGAGA - 3' }\end{array}$ & \\
\hline \multirow[t]{2}{*}{$\mathrm{IL}-4$} & \multirow[t]{2}{*}{ AJ621249 } & Forward 5'- GTGCCCACGCTGTGCTTAC -3' & \multirow[t]{2}{*}{82} \\
\hline & & $\begin{array}{l}\text { Reverse } \\
\text { 5'- AGGAAACСTCTСССTGGATGTC -3' }\end{array}$ & \\
\hline \multirow[t]{2}{*}{ 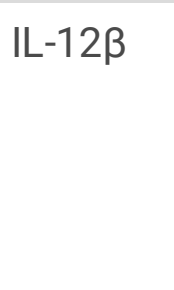 } & \multirow[t]{2}{*}{ AJ564202 } & $\begin{array}{l}\text { Forward 5'- } \\
\text { TGTCTCACCTGCTATTTGCCTTAC - 3' }\end{array}$ & \multirow[t]{2}{*}{87} \\
\hline & & $\begin{array}{l}\text { Reverse5'- } \\
\text { CATACACATTCTCTCTAAGTTTCCACTGT - } \\
3^{\prime}\end{array}$ & \\
\hline \multirow[t]{2}{*}{ HSP27 } & \multirow[t]{2}{*}{ NM_205290.1 } & $\begin{array}{l}\text { Forward 5'-ACACGAGGAGAAACAGGATGAG- } \\
3^{\prime}\end{array}$ & \multirow[t]{2}{*}{158} \\
\hline & & Reverse 5'-ACTGGATGGCTGGCTTGG - 3' & \\
\hline \multirow[t]{2}{*}{ HSP40 } & \multirow[t]{2}{*}{ NM_001199325.1 } & Forward 5'- GGGCATTCAACAGCATAGA - 3' & \multirow[t]{2}{*}{151} \\
\hline & & Reverse 5'- TTCACATCCCCAAGTTTAGG - 3' & \\
\hline \multirow[t]{2}{*}{ HSP60 } & \multirow[t]{2}{*}{ NM_001012916.1 } & Forward 5' - AGCCAAAGGGCAGAAATG - 3' & \multirow[t]{2}{*}{208} \\
\hline & & Reverse 5'- TACAGCAACAACCTGAAGA - 3' & \\
\hline \multirow[t]{2}{*}{ HSP70 } & \multirow[t]{2}{*}{ NM_001006685.1 } & Forward 5'- CGGGCAAGTTTGACCTAA - 3' & \multirow[t]{2}{*}{250} \\
\hline & & Reverse 5'- TTGGCTCCCACССTATCTCT - 3' & \\
\hline \multirow[t]{2}{*}{ HSP90 } & \multirow[t]{2}{*}{ NM_001109785.1 } & Forward 5'- TCCTGTCCTGGCTTTAGTTT - 3' & \multirow[t]{2}{*}{143} \\
\hline & & Reverse 5'- AGGTGGCATCTCCTCGGT - 3' & \\
\hline \multirow[t]{2}{*}{ ATG5 } & \multirow[t]{2}{*}{ gi|449273598 } & $\begin{array}{l}\text { Forward 5'- } \\
\text { GATGAAATAACTGAAAGGGAAGC - 3' }\end{array}$ & \multirow[t]{2}{*}{208} \\
\hline & & $\begin{array}{l}\text { Reverse 5'- TGAAGATCAAAGAGCAAACCAA- } \\
3^{\prime}\end{array}$ & \\
\hline \multirow[t]{2}{*}{ Beclin 1} & \multirow[t]{2}{*}{ NM_001006332.1 } & Forward 5'- CAGACACGCTGCTGGACC - 3' & \multirow[t]{2}{*}{114} \\
\hline & & $\begin{array}{l}\text { Reverse 5'- TCTCCTTGTCATCCTCGTTCA - } \\
3^{\prime}\end{array}$ & \\
\hline Dynein & NM_001006519.1 & $\begin{array}{l}\text { Forward 5'- TGGGATAATCGCAGCAATAAGA } \\
-3^{\prime}\end{array}$ & 243 \\
\hline
\end{tabular}




\begin{tabular}{|c|c|c|c|}
\hline $\begin{array}{l}\text { Gene } \\
\text { name }\end{array}$ & $\begin{array}{l}\text { Accession } \\
\text { number }\end{array}$ & Primer sequence & $\begin{array}{l}\text { Size of the } \\
\text { products (bp) }\end{array}$ \\
\hline & & $\begin{array}{l}\text { Reverse 5'- } \\
\text { AGGGAAGGACATGCAAGTAACAG - 3' }\end{array}$ & \\
\hline \multirow[t]{2}{*}{ LC3-I } & \multirow[t]{2}{*}{ gi|311294088 } & $\begin{array}{l}\text { Forward 5'- GCATCCAAACAAAATCCCAGTC } \\
-3^{\prime}\end{array}$ & \multirow[t]{2}{*}{246} \\
\hline & & $\begin{array}{l}\text { Reverse 5'- AAGCCATCCTCATCCTTCTCCT - } \\
3^{\prime}\end{array}$ & \\
\hline \multirow[t]{2}{*}{ LC3-II } & \multirow[t]{2}{*}{ NM_001031461.1 } & Forward 5 - СТTСTTССTССTGGTGAACG-3' & \multirow[t]{2}{*}{131} \\
\hline & & Reverse 5'- GCACTCCGAAAGTCTCCTGA-3' & \\
\hline \multirow[t]{2}{*}{ mTOR } & \multirow[t]{2}{*}{ XM_417614.5 } & $\begin{array}{l}\text { Forward 5'- GGACTCTTCCCTGCTGGCTAA - } \\
3^{\prime}\end{array}$ & \multirow[t]{2}{*}{143} \\
\hline & & Reverse 5'- TACGGGTGCCCTGGTTCTG - 3' & \\
\hline \multirow[t]{2}{*}{ GAPDH } & \multirow[t]{2}{*}{ NM_204305.1 } & Forward 5 - AGAACATCATCCCAGCGT - 3' & \multirow[t]{2}{*}{128} \\
\hline & & Reverse 5'- AGCСТTСАСТАСССТСТTG - 3' & \\
\hline
\end{tabular}

Total RNA was extracted from kidney tissues with TRIzol reagent following the method provided by the manufacturer (Invitrogen, China). Spectrophotometer (Healthcare Bio-Sciences AB, Sweden) was used to determine RNA purity. OD260/OD280 was between 1.8 and 2.1, and met the experimental requirements. Complementary DNA (cDNA) was synthesized with PrimeScript ${ }^{\mathrm{TM}}$ RT reagent Kit (TaKaRa, Japan) in a volume of $60 \mu \mathrm{L}$ (containing $5 \mu \mathrm{g}$ of the total RNA) according to the manufacturer's instructions. Obtained cDNA was diluted fivefold with sterile water and was kept at $-20^{\circ} \mathrm{C}$ until next step.

Quantitative real-time PCR was performed using LightCycler ${ }^{\circledR} 96$ (Roche, Life Science) with the SYBR ${ }^{\circledR}$ PrimeScript TM RT-PCR Kit (Roche, Switzerland) following manufacturer's instructions. The reaction system comprised $0.3 \mu \mathrm{L}$ of forward primer $(10 \mu \mathrm{M}), 0.3 \mu \mathrm{L}$ of reverse primer $(10 \mu \mathrm{M}), 1 \mu \mathrm{L}$ of diluted cDNA, 3.4 $\mu \mathrm{L}$ of sterile distilled water, and $5 \mu \mathrm{L}$ of $2 \times$ SYBR green PCR master mix (Takara, China). The PCR procedure was as follows: at $52^{\circ} \mathrm{C}$ for $2 \mathrm{~min}$ and $95^{\circ} \mathrm{C}$ for $10 \mathrm{~min}$; followed by 40 cycles of amplification and quantification at $95^{\circ} \mathrm{C}$ for $15 \mathrm{~s}$, at $60^{\circ} \mathrm{C}$ for $60 \mathrm{~s}$, and at $95^{\circ} \mathrm{C}$ for $15 \mathrm{~s}$; and at $60^{\circ} \mathrm{C}$ for $20 \mathrm{~s}$. Each sample was repeated three times. Relative mRNA expression was calculated according to the $2^{-\triangle \Delta} \mathrm{CT}$ method.

\section{Western blot analysis}

Kidney tissues (about $50 \mathrm{mg}$ ) were cut from each kidney and washed in saline, and then were sliced and homogenized in sodium dodecyl sulfate (SDS) lysate. Homogenate solution was centrifuged and were extracted supernatant. Protein quantification was detected with BCA protein assay kits (Thermo Scientific, USA). Then, proteins were put into SDS-PAGE gel and were transferred to the membranes of nitrocellulose at $200 \mathrm{~mA}$ for $1 \mathrm{~h}$. The membranes were put into $5 \%$ skim milk to block at $4{ }^{\circ} \mathrm{C}$ for $12 \mathrm{~h}$. The 
antibodies were diluted to 1:1000 (HSP27), 1:1000 (HSP40), 1:1000 (HSP60), 1:500 (HSP70), 1:500 (HSP90), 1:100 (LC3-囚and LC3-囚), 1:500 (Dynein and mTOR), and 1:1000 (ATG5 and Beclin 1), respectively. After being washed for four 5-min periods with PBST, the membranes reacted with secondary antibodies against rabbit IgG $\left(1: 1000\right.$, Santa Cruz, USA) at $37^{\circ} \mathrm{C}$ for $1 \mathrm{~h}$. Then the membranes were washed for four 5-min periods. Western blotting detection kits (Thermo Scientific, USA) were used for detecting protein expression. The membranes were exposed X-ray films. Then, protein levels were analyzed using image VCD gel imaging system (Beijing Sage Creation Science and Technology Co. Ltd., Beijing, China). The GAPDH signal was used as an internal reference.

\section{Statistical analysis}

All experiment data were presented as the mean \pm standard deviation (SD). One-way and two-way analyses of variance (ANOVA) were performed using SPSS (version 21.0, SPSS Inc., Chicago, IL, USA). Kruskal-Wallis ANOVA test and Mann-Whitney $U$ test were used to compare difference among multiple groups. Statistical significance was assigned at $P<0.05$.

\section{Results}

\section{Histology alterations}

To explore the effect of $\mathrm{Pb}$ on chicken kidneys and mitigative effect of $\mathrm{Se}$ on $\mathrm{Pb}$ poisoning, chickens were treated with $\mathrm{Pb}$ and Se for 90 days. Histology alterations of chicken kidneys were shown in Fig. 1 on 90th day. In I group (Fig. 1(A1)) and II group (Fig. 1(B1)), glomerular structure was clear and glomerular cavity was clearly visible. In III group (Fig. 1(C1)), glomerulus was swollen, the boundaries of renal cyst were unclear, renal tubular epithelial cells were swollen, inflammatory cells infiltrated extensively, and vacuolization occurred compared with I group. In IV group (Fig. 1(D1), glomerulus was slightly swollen, the margin of renal cyst was little blurred, renal tubular epithelial cells were slightly swollen, and inflammatory infiltration decreased compared with $₫$ group.

Ultrastructure results of chicken kidneys were as follows: Organelles were normal in $\nabla$ group (Fig. (A2))

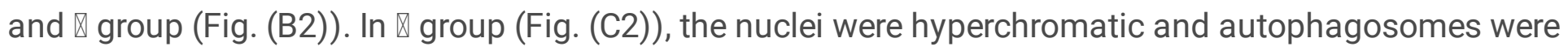

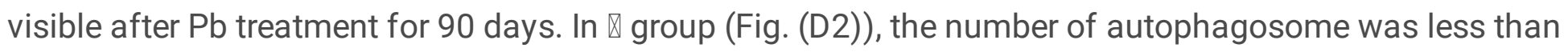
that in $\otimes$ group.

\section{T-AOC, GST , and CAT activities and H2O2 content in chicken kidneys}

To assess the effect of $\mathrm{Pb}$ treatment on oxidative stress and mitigative effect of $\mathrm{Se}$, oxidative stress indexes including T-AOC, GST, CAT, and $\mathrm{H}_{2} \mathrm{O}_{2}$ were measured on 30th, 60th, and 90th days. As shown in Fig. 3 , there were significant differences $(P<0.05)$ in T-AOC (Fig. $3(A)$ ), GST (Fig. $3(B)$ ), and CAT (Fig. 3 (C)) activities and $\mathrm{H}_{2} \mathrm{O}_{2}$ (Fig. 3 (D)) content among different groups except there were no significant difference $(P>0.05)$ in T-AOC, GST, and CAT activities and $\mathrm{H}_{2} \mathrm{O}_{2}$ content between $\nabla$ group and $\otimes$ group at 


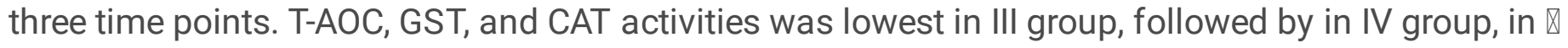
group and $₫$ group at three time points. Change tendency of $\mathrm{H}_{2} \mathrm{O}_{2}$ content was opposite to that of T-AOC, GST, and CAT activities at three time points. In addition, T-AOC, GST, and CAT activities decreased significantly $(P<0.05)$ with the increase of treatment duration, but $\mathrm{H}_{2} \mathrm{O}_{2}$ content showed opposite trend $(P<0.05)$ in III group.

\section{Relative mRNA expression of IL-2, IL-4, and IL-12 $\beta$}

To investigate the effects of $\mathrm{Pb}$ and $\mathrm{Se}$ on the inflammation of chicken kidneys, the expression of IL-2, IL4 , and IL-12 $\beta$ was detected on 30th, 60th, and 90th days (Fig. 3). Pb treatment caused a notable decrease in IL-2 mRNA expression and increase in IL-4 and IL-12 $\beta$ mRNA expression in chicken kidneys $(P<0.05)$. Se administration significantly induced IL-2 mRNA expression and reduced IL-4 and IL-12 $\beta$ mRNA expression $(P<0.05)$. In addition, IL-2 mRNA expression decreased significantly $(P<0.05)$ and IL-4 and IL$12 \beta$ mRNA expression increased significantly $(P<0.05)$ with the increase of treatment duration in $\otimes$ group.

\section{Relative mRNA and protein expression of HSP27, HSP40, HSP60, HSP70, and HSP90}

To detect the effect of $\mathrm{Pb}$ and Se on heat shock response in chicken kidneys, mRNA and protein expression of HSP27, HSP40, HSP60, HSP70, and HSP90 was measured on 30th, 60th, and 90th days (Fig. 4). Pb treatment led to notably increase $(P<0.05)$ in mRNA and protein expression of HSP27, HSP40, HSP60, HSP70, and HSP90 in the chicken kidneys, while chickens with Se administration showed significant recovery $(P<0.05)$ of mRNA and protein expression of HSPs as compared with $\square$ group (Fig. 3). However, there was no significant difference $(P>0.05)$ in mRNA and protein expression of HSP27, HSP40, HSP60, HSP70, and HSP90 between I group and II group. In addition, mRNA expression of all the above detected HSPs increased significantly $(P<0.05)$ with the increase of treatment duration in $\nabla$ group.

\section{Relative mRNA and protein levels of ATG5, Beclin 1, Dynein, LC3-I, LC3-II, and mTOR}

To determine mitigative effect of Se on autophagy in Pb-treated chicken kidneys, the expression of autophagy-related genes including ATG5, Beclin 1, Dynein, LC3-I, LC3-II, and mTOR was evaluated on 90th day. As shown in Fig. 5, a notable increase in mRNA and protein expression of ATG5, Beclin 1, Dynein, LC3-I, and LC3-II and decrese in mRNA and protein expression of mTOR was observed in the Pb-treated chicken kidneys ( $P<0.05$, vs. I group or II group). However, Se intervetion significantly decreased the expression of above autophagy-related genes except that mTOR was increased $(P<0.05)$.

\section{Discussion}

Frequent environmental and occupational exposure to $\mathrm{Pb}$ has been well-established to induce organ toxicity and subsequent adverse pathological consequences. Many of these diverse toxic effects are manifested at both cellular and molecular levels and share common mechanisms of action across 
various tissues and organs. Excessive $\mathrm{Pb}$ exposure can cause histological alterations of chicken kidneys [23] and renal damage of rats [24]. Pb treatment caused tubular degeneration, cell swelling, and inflammatory infiltration in rat kidneys [25]. In this study, we found that $\mathrm{Pb}$ exerted toxicity in chicken kidneys according to typical features of pathological alterations after $\mathrm{Pb}$ treatment, such as swollen glomeruli, inflammatory infiltration, and vascularization.

It is well known that oxidative stress is a core mechanism of $\mathrm{Pb}$ toxicity due to imbalance in oxidant/antioxidant homeostasis [26]. Excessive $\mathrm{Pb}$ was absorbed to tissues which overproduced $\mathrm{H}_{2} \mathrm{O}_{2}$ [27]. Similar result has revealed that $\mathrm{H}_{2} \mathrm{O}_{2}$ level elevated in the particulate matter component-induced oxidative stress in transformed human airway epithelial cells [28]. $\mathrm{H}_{2} \mathrm{O}_{2}$, a typical oxidant, is capable of diffusing throughout the mitochondria and across cell membranes and producing many types of cellular injury [29]. Moreover, Pb depletes cells antioxidants, particularly thiolcontaining compounds (GST) and antioxidant enzymes (CAT and T-AOC) during oxidative stress [27]. GST is one of the predominant antioxidant enzymes against oxidative stress in living organisms [30]. CAT is a primary defense against oxidative stress, and can catalyze the conversion of $\mathrm{H}_{2} \mathrm{O}_{2}$ into oxygen and water [31]. At the same time, it is a potential target of $\mathrm{Pb}$ [32]. T-AOC is used to measure the amount of free radical purge and evaluate antioxidant status [33]. It has been reported that changes in GST, T-AOC, CAT, and $\mathrm{H}_{2} \mathrm{O}_{2}$ were associated with $\mathrm{Pb}$ poisoning in rat kidneys $[34,35]$. $\mathrm{Pb}$ can decrease T-AOC, GST, and CAT activities; and increase $\mathrm{H}_{2} \mathrm{O}_{2}$ content; and cause oxidative stress in the bursa of Fabricius of chickens [36]. In our findings, the damage was clearly demonstrated by the production of $\mathrm{H}_{2} \mathrm{O}_{2}$, which was accompanied by depletion in the antioxidant enzymes' (T-AOC, GST, and CAT) activities in the chicken kidneys upon exposure to $\mathrm{Pb}$ compared to non-treated group, suggesting that $\mathrm{Pb}$ caused renal injury and oxidative stress in the chicken kidneys. These results supported the fact that $\mathrm{Pb}$ toxicity induced renal injury by increasing oxidative stress, and similar phenomena had been reported previously [37-39]. The consequence of the decrease in the level of T-AOC, CAT and GST was due to direct binding of Pb with their sulfhydryl groups [40], altering their function or suppressing their activities by $\mathrm{Pb}$ [41]. In addition, the decrease in CAT activity was also attributed to scavenging of $\mathrm{H}_{2} \mathrm{O}_{2}$ in Pb-intoxicated chickens. Therefore, the alterations of oxidative status, either by the overproduction of oxidants or deficit in antioxidant activity, was one of direct consequences of $\mathrm{Pb}$ toxicity in the chicken kidneys. In addition, we also found that T-AOC, CAT, GST, and $\mathrm{H}_{2} \mathrm{O}_{2}$ changed in a time-dependent effect in the $\mathrm{Pb}$-induced chicken kidneys. It suggested that oxidative stress was gradually strengthened with $\mathrm{Pb}$ treatment duration. Our previous experiment also reported that $\mathrm{Pb}$ had a time-dependent effect on T-AOC, GST, and CAT activities and $\mathrm{H}_{2} \mathrm{O}_{2}$ content in chicken bursa of Fabricius [36].

Inflammatory response is the first line of defense in response to all forms of cellular injuries and clears cellular damage and initiates cellular repair [42]. But when inflammatory response is inappropriate it can lead to damage of surrounding normal cells. One of the events that occurred following oxidative stress is inflammatory response. It has been reported that increased oxidative stress might stimulate the expression of cytokines leading to increased inflammation [43]. IL-4 and IL-12 $\beta$ were proinflammatory mediators and IL-2 was anti-inflammatory one. Thus, in present study, IL-2, IL-4, and IL-12 $\beta$ were selected 
for mRNA expression analysis. We found that Pb treatment increased IL-4 and IL-12 $\beta$ and decreased IL-2 in the chicken kidneys, suggesting that $\mathrm{Pb}$ enhanced inflammatory process after oxidative stress in the chicken kidneys. As reported by Khatlab et al. (2019), reducing IL-2 expression level as the consequent of inflammatory response induced by Eimeria spp. challenge in broiler chickens [39]. The process of abnormal $\mathrm{Pb}$ invasion-caused oxidative stress triggered inflammatory response, through the cytokine production, such as IL-4 and IL-12 3 , which led to a reduction in the anti-inflammatory cytokine production, such as IL-2, and consequently, cells were damaged. In fact, inflammatory damage has been known to occur during the process of inflammation after $\mathrm{Pb}$ treatment, which was clearly seen from our histological results. Moreover, the increase of $\mathrm{H}_{2} \mathrm{O}_{2}$ level could cause structural damage to membranes. Our findings suggested a crosstalk between $\mathrm{Pb}$-induced oxidative stress and inflammation. Other researchers also concluded that there was a relationship between oxidative stress and inflammation. [44] found that lipopolysaccharide decreased CAT activity and increased $\mathrm{H}_{2} \mathrm{O}_{2}$ content with the increase of IL4 in chicken myocardial [44]. Abd El-Ghffar et al. (2018) reported that $\mathrm{H}_{2} \mathrm{O}_{2}$ content increased, GST and CAT activities decreased, and oxidative stress occurred which prompt expression of IL-4 in aspirin-treated mouse stomaches [45]. In addition, we also found that IL-2, IL-4, and IL- $12 \beta$ mRNA expressed in a timedependent effect in the $\mathrm{Pb}$-induced chicken kidneys, which suggested that inflammatory response was gradually strengthened with $\mathrm{Pb}$ treatment duration.

Oxidative stress is also responsible for activation of heat shock response [46]. HSPs also play a role in sensing oxidative stress, are involved in restoring physiological protein conformation during and after oxidative stress, and which are characteristic features of a number of pathological conditions. In response to oxidative stress, the expression of HSPs elevates dramatically which is notable as a pervasive adaptation mechanism in organisms that enables them to survive and adapt to different environmental stressors [46]. Increased levels of HSPs were an indicative of initiation of a stress response for mediating cellular protection and indicated tissue damage [47]. Heat shock response can protect against toxicity caused by excess heavy metals [48]. Previous studies reported that Pb increased HSPs (HSP27, HSP40, HSP60, HSP70, and HSP90 mRNA expression in peripheral blood neutrophils [49] and hearts [50] of chickens. In the present study, we observed high expression of HSPs (HSP27, HSP40, HSP60, HSP70, and HSP90) mRAN and protein caused by Pb exposure in the chicken kidneys, reflected the activation of this intracellular buffer system, which responds to oxidative stress when the antioxidant enzyme (T-AOC, GST, and CAT) exhaustion occurs [46]. The findings of this study indicated that $\mathrm{Pb}$ exposure resulted in the activation of HSPs under burden of oxidative stress. Interestingly, increasing evidence suggests that there is a complementary regulation between HSPs and inflammation [46]. Besides, inflammation is itself a stimulus for upregulation of HSPs production [51]. Therefore, in our study, elevated HSPs, on the one hand, antagonized the mentioned $\mathrm{Pb}$-induced oxidative stress, on the other hand, inhibited inflammation. In addition, we also found that HSP27, HSP40, HSP60, HSP70, and HSP90 mRNA expression increased in a time-dependent effect in the Pb-induced chicken kidneys. It suggested that HSP response was gradually strengthened with $\mathrm{Pb}$ treatment duration. 
Autophagy is an intracellular lysosomal degradation process, which plays an important role in regulating normal cell homeostasis, and is considered as one of cellular defense against increased oxidative stress [52]. Song et al. (2017) reported that autophagy contributed to $\mathrm{Pb}$-induced nephrotoxicity in primary rat proximal tubular cells [53]. Pb promoted protein levels of Beclin1, LC3-I, and LC3-II; and induced autophagy in rat hippocampi [54]. Han et al. (2017) reported that Pb increased mRNA and protein levels of ATG5, Beclin-1, Dynein, LC3-I, and LC3-II; decreased mRNA and protein levels of mTOR; and induced autophagy in chicken spleens [12]. Our present research is consistent with above studies. We found that $\mathrm{Pb}$ treatment promoted mRNA and protein expression of Beclin 1, Dynein, ATG 5, LC3-I, and LC3-Il; and inhibited mRNA and protein expression of mTOR. As reported by Wang et al. (2019), the increased mTOR expression were detected in weaned pigs compare with dietary tributyrin supplemented weaned pigs [55]. Furthermore, we found typical features of autophagy, formation of autophagosome, through the ultrastructure of chicken kidneys. Molecular and histology evidence of our study demonstrated that $\mathrm{Pb}$ induced autophagy in the chicken kidneys. Therefore, we concluded that elevated HSPs (HSP27, HSP40, HSP60, HSP70, and HSP90) were also a trigger for autophagy in $\mathrm{Pb}$ treatment group.

Previous studies have confirmed potent antioxidative and anti-inflammatory activities of Se. Some researches demonstrated that Se mitigated $\mathrm{Pb}$-induced oxidative stress by means of increasing T-AOC, GST, and CAT activities; and decreasing $\mathrm{H}_{2} \mathrm{O}_{2}$ content in Cyprinus carpio livers [56], chicken bursa of Fabricius [36], and chicken splenic lymphocytes [57]. Jiao et al. (2017) found that Se can mitigate increase of IL-4 and IL-12 $\beta$ mRNA expression, and the decrease of IL-2 mRNA expression in Pb-treated chicken bursa of Fabricius [36]. Xing et al. (2018)reported that Se alleviated the increase of IL-4 and IL$12 \beta$ mRNA expression and the decrease of IL-2 mRNA expression caused by Pb in chicken neutrophils [49]. In addition, Se can mitigate Pb-caused increase of HSPs and autophagy. Wang et al. (2017) found that $\mathrm{Pb}$ poisoning induced mRNA expression of HSP27, HSP40, HSP60, HSP70, and HSP90; and Se administration alleviated the above HSPs changes in chicken testes [19]. Se exhibited significant antagonistic roles against Pb-induced increases of $\operatorname{HSP}(27,40,60,70$, and 90$)$ mRNA expression in peripheral blood neutrophils [49] and hearts [50] of chickens. Se was reported by one of the articles to alleviate spleen toxicity in a chicken model induced by $\mathrm{Pb}$ via the modulation of oxidative stress, inflammation, and autophagy [12]. Se alleviated protein increase of ATG5, Beclin1, Dynein, LC3-I, and LC3II and protein decrease of mTOR in Cd-induced chicken pancreas [58]. In our study, all alterations caused by $\mathrm{Pb}$ were ameliorated by treatment with $\mathrm{Se}$. Such effect was attributed to kidney tissue antioxidant capacity because of better antioxidant supply, thus reducing the oxidative damage represented by the reduction of T-AOC, GST, and CAT and the rise of $\mathrm{H}_{2} \mathrm{O}_{2}$. The ability of Se to neutralize oxidative stress could be due to facilitating chelation with $\mathrm{Pb}$ in the chicken kidney tissues, resulting in reduced $\mathrm{Pb}$ accumulation in the body through its potential antioxidant efficacy [59]. So Se alleviated oxidative stress, which naturally alleviated these downstream events. Therefore, Se alleviates heat shock response and autophagy.

\section{Conclusion}


Excessive $\mathrm{Pb}$ led to oxidative stress, which further triggered a defensive response including heat shock response, inflammatory response, and autophagy in the chicken kidneys. Se alleviated heat shock response, inflammatory response, and autophagy in the $\mathrm{Pb}$-treated chicken kidneys. In addition, the effects of $\mathrm{Pb}$ poisoning had time-dependent manners in the chicken kidneys.

\section{Abbreviations}

ANOVA: analyses of variance; ATG5: Autophagy-related protein 5; CAT: Catalase; cDNA: Complementary DNA; D: Standard diet; EDTA: Ethylene diamine tetraacetic acid; GAPDH: Glyceraldehyde-3-phosphate dehydrogenase; GST: Glutathione-s-transferase; HSPs: Heat shock proteins; Interleukin-12 $\beta$ : IL-12 $\beta$; Interleukin-2: IL-2; interleukin-4: IL-4; LC3: Light chain 3; Pb: Lead; SD: Standard deviation; SDS: Sodium dodecyl sulfate; Se: Selenium; T-AOC: Total antioxidant capacity; W: Potable water;

\section{Declarations}

\section{Acknowledgments}

Not applicable

\section{Authors' contributions}

X.G. and X.T. conceived and designed the study. Z.M. and W.Y. performed the literature search, generated the figures and table, and wrote the manuscript. Z.M., W.Y. and Y.W. collected and analyzed the data, and critically reviewed the manuscript. X.G. and X.T. supervised the study and reviewed the manuscript. All authors submitted comments on drafts and read and approved the final manuscript.

\section{Funding}

The study was supported by National Natural Science Foundation of China (No. 31972612), The Heilongjiang Province on National Fund Project of China (No. LH2019C026), The Agricultural Science and Technology Innovation Program (ASTIP-IAS07), China Agriculture Research System (No. CARS-41).

\section{Availability of data and materials}

All data generated or analyzed during this study are included in this published article. The origin sequences for GAPDH, inflammatory genes (including IL-2, IL-4 and IL-12 $\beta$ ); HSPs genes (including HSP27, HSP40, HSP60, HSP70, HSP90), and the genes of autophagy (including ATG5, Beclin 1, Dynein, LC3- I, LC3-II and mTOR) used in qRT-PCR part of this study are deposited in GeneBank (NCBI) under Nucleotide (https://www.ncbi.nlm.nih.gov/nuccore).

\section{Ethics approval and consent to participate}


All procedures used in this experiment were approved by the Northeast Agricultural University's Institutional Animal Care and Use Committee under the approved protocol number SRM-06.

\section{Consent for publication}

Not applicable

\section{Competing interests}

The authors declare that they have no conflicts of interest

\section{Author details}

${ }^{1}$ College of Animal Science and Technology, Northeast Agricultural University, Harbin, 150030, China

2 The Fourth Affiliated Hospital of Harbin Medical University, Harbin, 150030, China

${ }^{3}$ State Key Laboratory of Animal Nutrition, Institute of Animal Sciences, Chinese Academy of Agricultural Sciences, Beijing, 100193, China

\section{References}

1. Mohammadi M, Ghaznavi R, Keyhanmanesh R, Sadeghipour HR, Naderi R, Mohammadi H. Caloric restriction prevents lead-induced oxidative stress and inflammation in rat liver. ScientificWorldJournal. 2014;2014:821524.

2. Patrick L. Lead toxicity, a review of the literature. Part 1: Exposure, evaluation, and treatment. Altern Med Rev. 2006;11:2-22.

3. Sancar F. Childhood Lead Exposure May Affect Personality, Mental Health in Adulthood. JAMA. 2019;321:1445-6.

4. Green RE, Pain DJ. Risks to human health from ammunition-derived lead in Europe. Ambio. 2019;48:954-68.

5. De Francisco N, Ruiz Troya JD, Aguera El. Lead and lead toxicity in domestic and free living birds. Avian Pathol. 2003;32:3-13.

6. Finkelstein ME, Doak DF, George D, et al. Lead poisoning and the deceptive recovery of the critically endangered California condor. Proc Natl Acad Sci U S A. 2012;109:11449-54.

7. Thomas RS, Bahadori T, Buckley TJ, et al. The Next Generation Blueprint of Computational Toxicology at the US Environmental Protection Agency. Toxicol Sci. 2019;169:317-32.

8. Tenorio MB, Ferreira RC, Moura FA, Bueno NB, de Oliveira ACM, Goulart MOF. Cross-Talk between Oxidative Stress and Inflammation in Preeclampsia. Oxid Med Cell Longev. 2019;2019:8238727.

9. Hang K, Ye C, Chen E, Zhang W, Xue D, Pan Z. Role of the heat shock protein family in bone metabolism. Cell Stress Chaperones. 2018;23:1153-64. 
10. Roca-Agujetas V, de Dios C, Leston L, Mari M, Morales A, Colell A. Recent Insights into the Mitochondrial Role in Autophagy and Its Regulation by Oxidative Stress. Oxid Med Cell Longev. 2019;2019:3809308.

11. Ayoub KF, Pothineni NVK, Rutland J, Ding Z, Mehta JL. Immunity, Inflammation, and Oxidative Stress in Heart Failure: Emerging Molecular Targets. Cardiovasc Drugs Ther. 2017;31:593-608.

12. Han Y, Li C, Su M, Wang Z, Jiang N, Sun D. Antagonistic effects of selenium on lead-induced autophagy by influencing mitochondrial dynamics in the spleen of chickens. Oncotarget. 2017;8:33725-35.

13. Corsetti G, Romano C, Stacchiotti A, Pasini E, Dioguardi FS. Endoplasmic Reticulum Stress and Apoptosis Triggered by Sub-Chronic Lead Exposure in Mice Spleen: a Histopathological Study. Biol Trace Elem Res. 2017;178:86-97.

14. Ge Y, Huang M, Yao YM. Autophagy and proinflammatory cytokines: Interactions and clinical implications. Cytokine Growth Factor Rev. 2018;43:38-46.

15. Chen F, Bao H, Xie H, Tian G, Jiang T. Heat shock protein expression and autophagy after incomplete thermal ablation and their correlation. Int J Hyperthermia. 2019;36:95-103.

16. Sun Z, Xu Z, Wang D, Yao H, Li S. Selenium deficiency inhibits differentiation and immune function and imbalances the Th1/Th2 of dendritic cells. Metallomics. 2018;10:759-67.

17. Huang H, An Y, Jiao W, Wang J, Li S, Teng X. CHOP/caspase-3 signal pathway involves in mitigative effect of selenium on lead-induced apoptosis via endoplasmic reticulum pathway in chicken testes. Environ Sci Pollut Res Int. 2018;25:18838-45.

18. Huang H, Wang Y, An Y, Tian Y, Li S, Teng X. Selenium for the mitigation of toxicity induced by lead in chicken testes through regulating mRNA expressions of HSPs and selenoproteins. Environ Sci Pollut Res Int. 2017;24:14312-21.

19. Wang Y, Wang K, Huang H, Gu X, Teng X. Alleviative effect of selenium on inflammatory damage caused by lead via inhibiting inflammatory factors and heat shock proteins in chicken testes. Environ Sci Pollut Res Int. 2017;24:13405-13.

20. Song GL, Chen C, Wu QY, et al. Selenium-enriched yeast inhibited beta-amyloid production and modulated autophagy in a triple transgenic mouse model of Alzheimer's disease. Metallomics. 2018;10:1107-15.

21. Vengris VE, Mare CJ. Lead poisoning in chickens and the effect of lead on interferon and antibody production. Can J Comp Med. 1974;38:328-35.

22. Huang $H$, Wang $Y, A n Y$, et al. Selenium alleviates oxidative stress and autophagy in lead-treated chicken testes. Theriogenology. 2019;131:146-52.

23. Jin $X, X u$ Z, Zhao X, Chen M, Xu S. The antagonistic effect of selenium on lead-induced apoptosis via mitochondrial dynamics pathway in the chicken kidney. Chemosphere. 2017;180:259-66.

24. Wang L, Lin S, Li Z, Yang D, Wang Z. Protective effects of puerarin on experimental chronic lead nephrotoxicity in immature female rats. Hum Exp Toxicol. 2013;32:172-85. 
25. Yurekli M, Esrefoglu M, Ilker Dogru M, Dogru A, Gul M, Whidden M. Adrenomedullin reduces antioxidant defense system and enhances kidney tissue damage in cadmium and lead exposed rats. Environ Toxicol. 2009;24:279-86.

26. Chander K, Vaibhav K, Ejaz Ahmed M, et al. Quercetin mitigates lead acetate-induced behavioral and histological alterations via suppression of oxidative stress, Hsp-70, Bak and upregulation of Bcl-2. Food Chem Toxicol. 2014;68:297-306.

27. Lopes AC, Peixe TS, Mesas AE, Paoliello MM. Lead Exposure and Oxidative Stress: A Systematic Review. Rev Environ Contam Toxicol. 2016;236:193-238.

28. Cheng WY, Currier J, Bromberg PA, Silbajoris R, Simmons SO, Samet JM. Linking oxidative events to inflammatory and adaptive gene expression induced by exposure to an organic particulate matter component. Environ Health Perspect. 2012;120:267-74.

29. Ray G, Husain SA. Oxidants, antioxidants and carcinogenesis. Indian J Exp Biol. 2002;40:1213-32.

30. Hayes JD, Flanagan JU, Jowsey IR. Glutathione transferases. Annu Rev Pharmacol Toxicol. 2005;45:51-88.

31. Ahn J, Gammon MD, Santella RM, et al. Associations between breast cancer risk and the catalase genotype, fruit and vegetable consumption, and supplement use. Am J Epidemiol. 2005;162:943-52.

32. Flora SJ, Mittal M, Mehta A. Heavy metal induced oxidative stress \& its possible reversal by chelation therapy. Indian J Med Res. 2008;128:501-23.

33. Zhang Y, Meng D, Wang Z, Guo H, Wang Y. Oxidative stress response in two representative bacteria exposed to atrazine. FEMS Microbiol Lett. 2012;334:95-101.

34. Apaydin FG, Bas H, Kalender S, Kalender Y. Subacute effects of low dose lead nitrate and mercury chloride exposure on kidney of rats. Environ Toxicol Pharmacol. 2016;41:219-24.

35. Oyagbemi AA, Omobowale TO, Akinrinde AS, Saba AB, Ogunpolu BS, Daramola O. Lack of reversal of oxidative damage in renal tissues of lead acetate-treated rats. Environ Toxicol. 2015;30:1235-43.

36. Jiao X, Yang K, An Y, Teng X, Teng X. Alleviation of lead-induced oxidative stress and immune damage by selenium in chicken bursa of Fabricius. Environ Sci Pollut Res Int. 2017;24:7555-64.

37. Gargouri M, Soussi A, Akrouti A, Magne C, El Feki A. Potential protective effects of the edible alga Arthrospira platensis against lead-induced oxidative stress, anemia, kidney injury, and histopathological changes in adult rats. Appl Physiol Nutr Metab. 2019;44:271-81.

38. Kelainy EG, Ibrahim Laila IM, Ibrahim SR. The effect of ferulic acid against lead-induced oxidative stress and DNA damage in kidney and testes of rats. Environ Sci Pollut Res Int. 2019;26:31675-84.

39. Khatlab AS, Del Vesco AP, de Oliveira Neto AR, Fernandes RPM, Gasparino E. Dietary supplementation with free methionine or methionine dipeptide mitigates intestinal oxidative stress induced by Eimeria spp. challenge in broiler chickens. J Anim Sci Biotechnol. 2019;10:58.

40. Saxena G, Pathak U, Flora SJ. Beneficial role of monoesters of meso-2,3-dimercaptosuccinic acid in the mobilization of lead and recovery of tissue oxidative injury in rats. Toxicology. 2005;214:39-56. 
41. Ercal N, Gurer-Orhan H, Aykin-Burns N. Toxic metals and oxidative stress part I: mechanisms involved in metal-induced oxidative damage. Curr Top Med Chem. 2001;1:529-39.

42. Sochocka M, Zwolinska K, Leszek J. The Infectious Etiology of Alzheimer's Disease. Curr Neuropharmacol. 2017;15:996-1009.

43. Reuter S, Gupta SC, Chaturvedi MM, Aggarwal BB. Oxidative stress, inflammation, and cancer: how are they linked? Free Radic Biol Med. 2010;49:1603-16.

44. Liu J, Wang S, Zhang Q, Li X, Xu S. Selenomethionine alleviates LPS-induced chicken myocardial inflammation by regulating the miR-128-3p-p38 MAPK axis and oxidative stress. Metallomics. 2020;12:54-64.

45. Abd El-Ghffar EA, Al-Sayed E, Shehata SM, Eldahshan OA, Efferth T. The protective role of Ocimum basilicum L. (Basil) against aspirin-induced gastric ulcer in mice: Impact on oxidative stress, inflammation, motor deficits and anxiety-like behavior. Food Funct. 2018;9:4457-68.

46. Kalmar B, Greensmith L. Induction of heat shock proteins for protection against oxidative stress. Adv Drug Deliv Rev. 2009;61:310-8.

47. De Maio A. Extracellular heat shock proteins, cellular export vesicles, and the Stress Observation System: a form of communication during injury, infection, and cell damage. It is never known how far a controversial finding will go! Dedicated to Ferruccio Ritossa. Cell Stress Chaperones. 2011;16:23549.

48. Zhu XN, Chen LP, Bai Q, et al. PP2A-AMPKalpha-HSF1 axis regulates the metal-inducible expression of HSPs and ROS clearance. Cell Signal. 2014;26:825-32.

49. Xing M, Jin X, Wang J, Shi Q, Cai J, Xu S. The Antagonistic Effect of Selenium on Lead-Induced Immune Dysfunction via Recovery of Cytokine and Heat Shock Protein Expression in Chicken Neutrophils. Biol Trace Elem Res. 2018;185:162-9.

50. Huang $H$, Jiao $X, X u Y$, et al. Dietary selenium supplementation alleviates immune toxicity in the hearts of chickens with lead-added drinking water. Avian Pathol. 2019;48:230-7.

51. Humphries HE, Triantafilou M, Makepeace BL, Heckels JE, Triantafilou K, Christodoulides M. Activation of human meningeal cells is modulated by lipopolysaccharide (LPS) and non-LPS components of Neisseria meningitidis and is independent of Toll-like receptor (TLR)4 and TLR2 signalling. Cell Microbiol. 2005;7:415-30.

52. Zhang W, Wan X, Liu Z, Xiao L, Huang H, Liu X. The emerging role of oxidative stress in regulating autophagy: applications of cancer therapy. Cell Mol Biol (Noisy-le-grand). 2017;63:67-76.

53. Song XB, Liu G, Liu F, et al. Autophagy blockade and lysosomal membrane permeabilization contribute to lead-induced nephrotoxicity in primary rat proximal tubular cells. Cell Death Dis. 2017;8:e2863.

54. Zhang J, Cai T, Zhao F, et al. The role of alpha-synuclein and tau hyperphosphorylation-mediated autophagy and apoptosis in lead-induced learning and memory injury. Int J Biol Sci. 2012;8:935-44.

55. Wang C, Cao S, Shen Z, et al. Effects of dietary tributyrin on intestinal mucosa development, mitochondrial function and AMPK-mTOR pathway in weaned pigs. J Anim Sci Biotechnol. 
2019;10:93.

56. Ozkan-Yilmaz F, Ozluer-Hunt A, Gunduz SG, Berkoz M, Yalin S. Effects of dietary selenium of organic form against lead toxicity on the antioxidant system in Cyprinus carpio. Fish Physiol Biochem. 2014;40:355-63.

57. Zhao D, Zhang X. Selenium Antagonizes the Lead-Induced Apoptosis of Chicken Splenic

Lymphocytes In Vitro by Activating the PI3K/Akt Pathway. Biol Trace Elem Res. 2018;182:119-29.

58. Liu R, Jia T, Cui Y, Lin H, Li S. The Protective Effect of Selenium on the Chicken Pancreas against Cadmium Toxicity via Alleviating Oxidative Stress and Autophagy. Biol Trace Elem Res. 2018;184:240-6.

59. Li M, Gao JQ, Li XW. [Antagonistic action of selenium against the toxicity of lead]. Wei Sheng Yan Jiu. 2005;34:375-7.

\section{Figures}
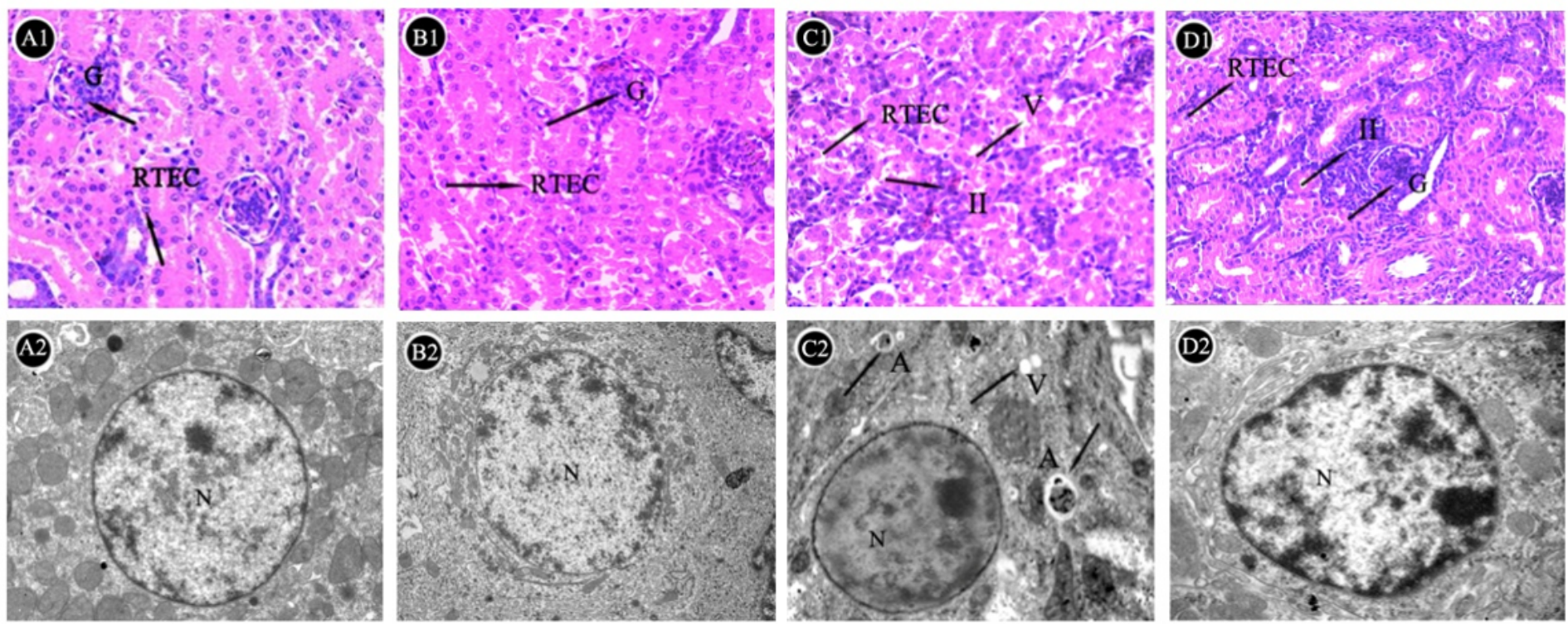

Figure 1

Effects of $\mathrm{Pb}, \mathrm{Se}$, and their co-treatment on histological alerations of chicken kidneys on 90th day. G: glomerulus; RTEC: renal tubular epithelial cell; II: inflammatory infiltration; V:vacuole; N: nucleus; A: autophagosome. Paraffin sections of kidney tissues from I (A1), $\otimes$ group (B1), $\Downarrow$ group (C1) and $\otimes$ group (D1) were stained with hematoxylin-eosin $(400 \times)$. $\otimes$ group showed glomerular fibrosis, blurring boundary of renal cysts, vacuolization, the swollen of renal tubular epithelial cells, and inflammatory infiltration (C1). The pathological injuries in 囚group were alleviated by Se administration (D1). Ultrathin sections of kidney tissues from I group (A2), $\otimes$ group (B2), $\otimes$ group (C2) and $\otimes$ group (D2) were tinted with uranyl acetate and lead citrate $(12,000 \times)$. $\otimes$ group showed mitochondrial swelling and mitochondrial cristae fracture (C2). The histological alterations in $₫$ group were alleviated by Se administration (D2). 
A

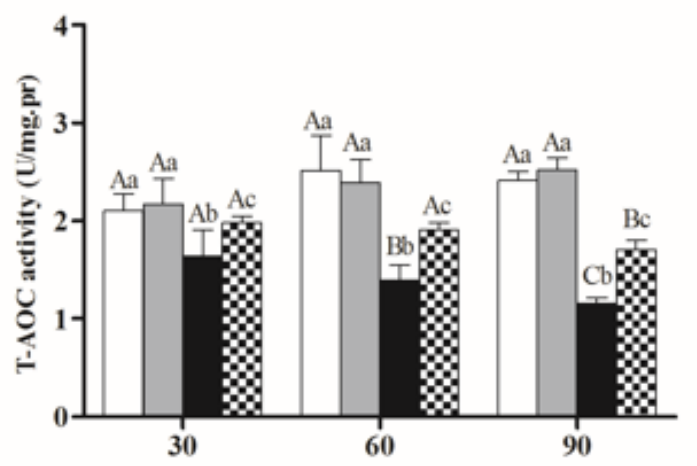

C

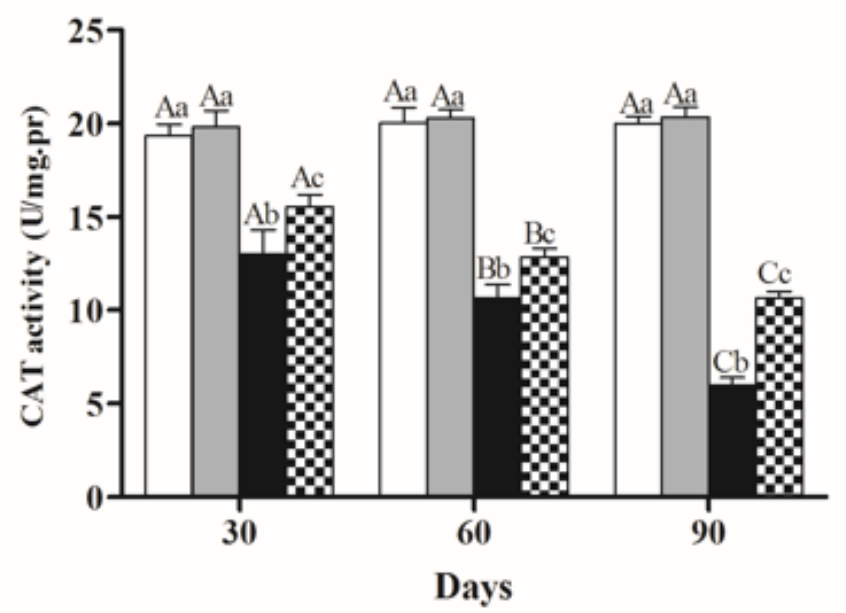

B

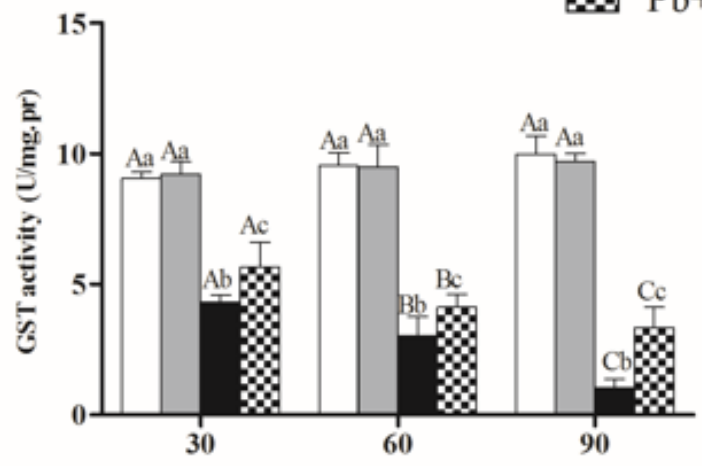

D

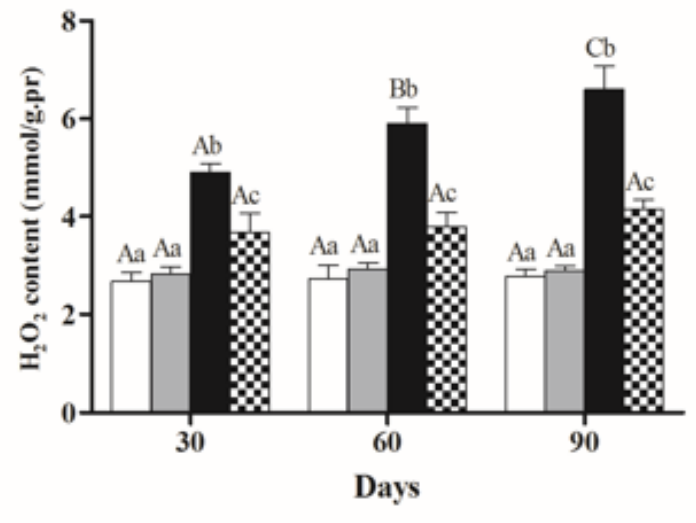

Figure 2

Effects of $\mathrm{Pb}, \mathrm{Se}$, and their co-treatment on oxidative stress indicators in chicken kidneys on 30th, 60th, and 90th days. T-AOC (A), GST (B), and CAT (C) activities and H2O2 (D) content were determined with commercial assay kits. Bars represent mean $\pm S D(n=5$ /group). In the same time point, the bars sharing different lowercase letters represent statistically significant differences between the groups $(P<0.05)$; the bars with a common letter are not significant different $(P>0.05)$. In the same group, the bars sharing different uppercase letters represent statistically significant differences in the different time points $(P<$ $0.05)$; the bars with a common letter are not significant different $(P>0.05)$. 
A B

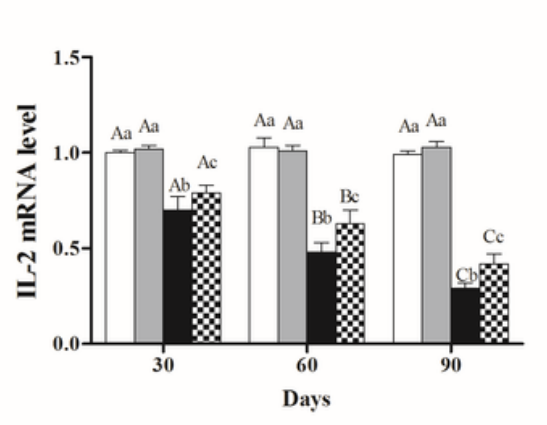

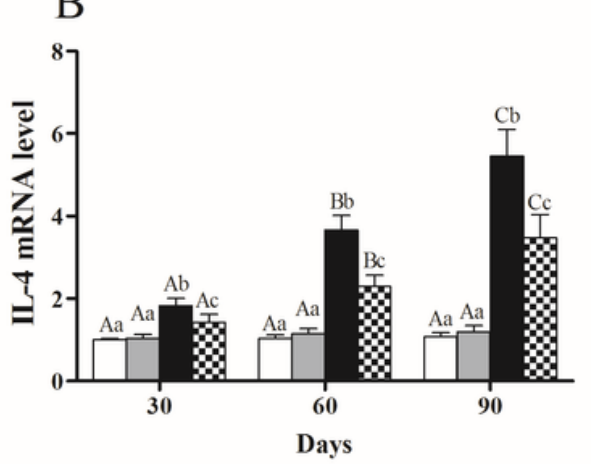

$\mathrm{C}$

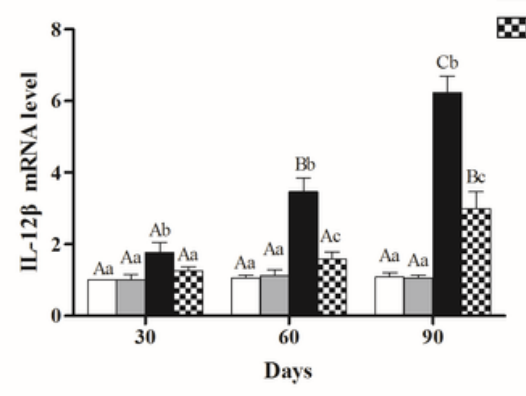

\section{Figure 3}

Effects of $\mathrm{Pb}, \mathrm{Se}$, and their co-treatment on mRNA expression of cytokines in chicken kidneys on 30th, 60th, and 90th days. IL-2 (A), IL-4 (B), and IL- $12 \beta$ (C) mRNA expression were determined by real-time PCR. Bars represent mean $\pm S D(n=5$ /group). In the same time point, the bars sharing different lowercase letters represent statistically significant differences between the groups $(P<0.05)$; the bars with a common letter are not significant different $(P>0.05)$. In the same group, the bars sharing different uppercase letters represent statistically significant differences in the different time points $(P<0.05)$; the bars with a common letter are not significant different $(P>0.05)$. 

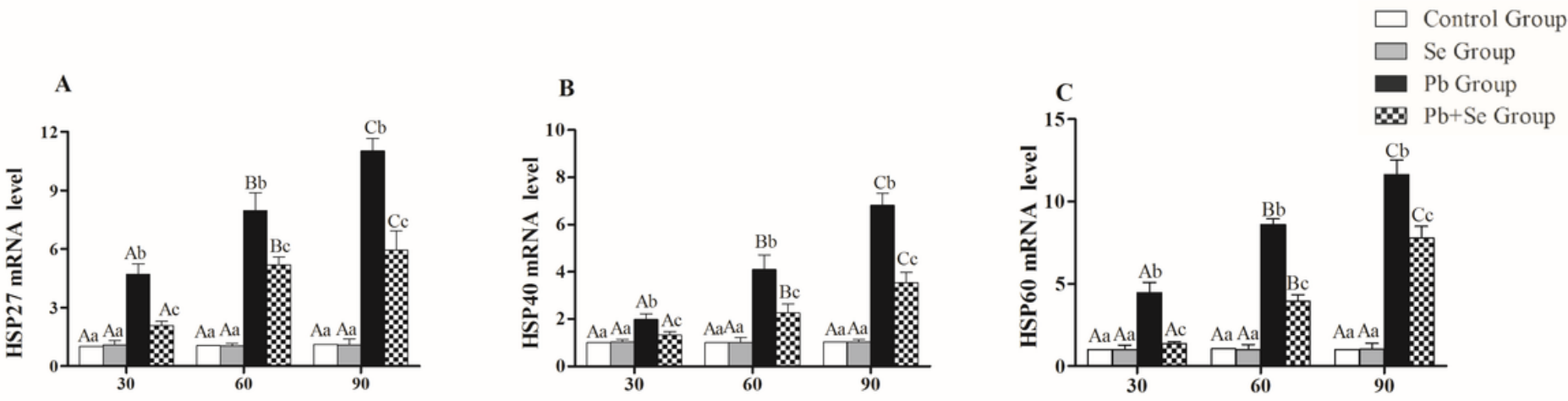

D

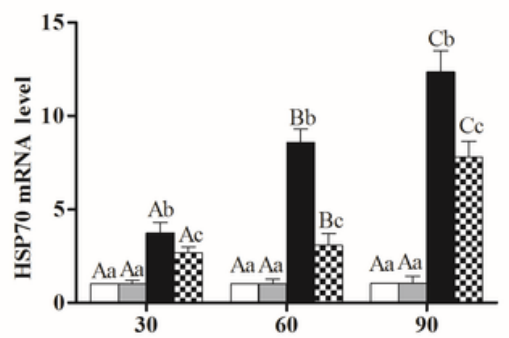

E

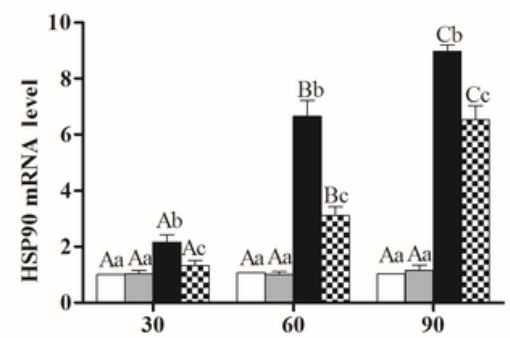

Control Se $\mathrm{Pb} \quad \mathrm{Pb}+\mathrm{Se}$

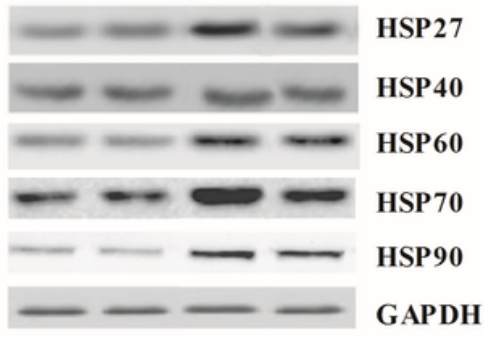

F

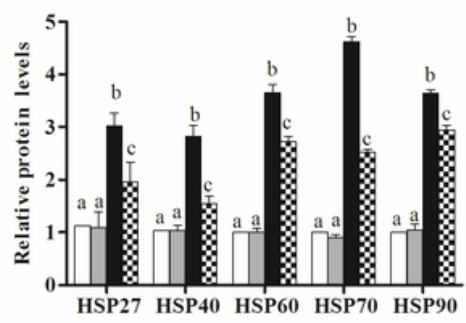

\section{Figure 4}

Effects of $\mathrm{Pb}, \mathrm{Se}$, and their co-treatment on mRNA and protein expressions of HSPs in chicken kidneys. HSP27 (A), HSP40 (B), HSP60 (C), HSP70 (D), and HSP90 (E) mRNA expressions were determined by realtime PCR and their protein expressions (F) were determined using Western-blot. Bars represent mean \pm SD ( $n=5 /$ group). In the same time point, the bars sharing different lowercase letters represent statistically significant differences between the groups $(P<0.05)$; the bars with a common letter are not significantly different $(P>0.05)$. In the same group, the bars sharing different uppercase letters represent statistically significant differences in the different time points $(P<0.05)$; the bars with a common letter are not significant different $(P>0.05)$. 

$\square$ Control Group
$\square$ Se Group
- $\mathrm{Pb}$ Group
$\$ \mathrm{~Pb}+\mathrm{Se}$ Group
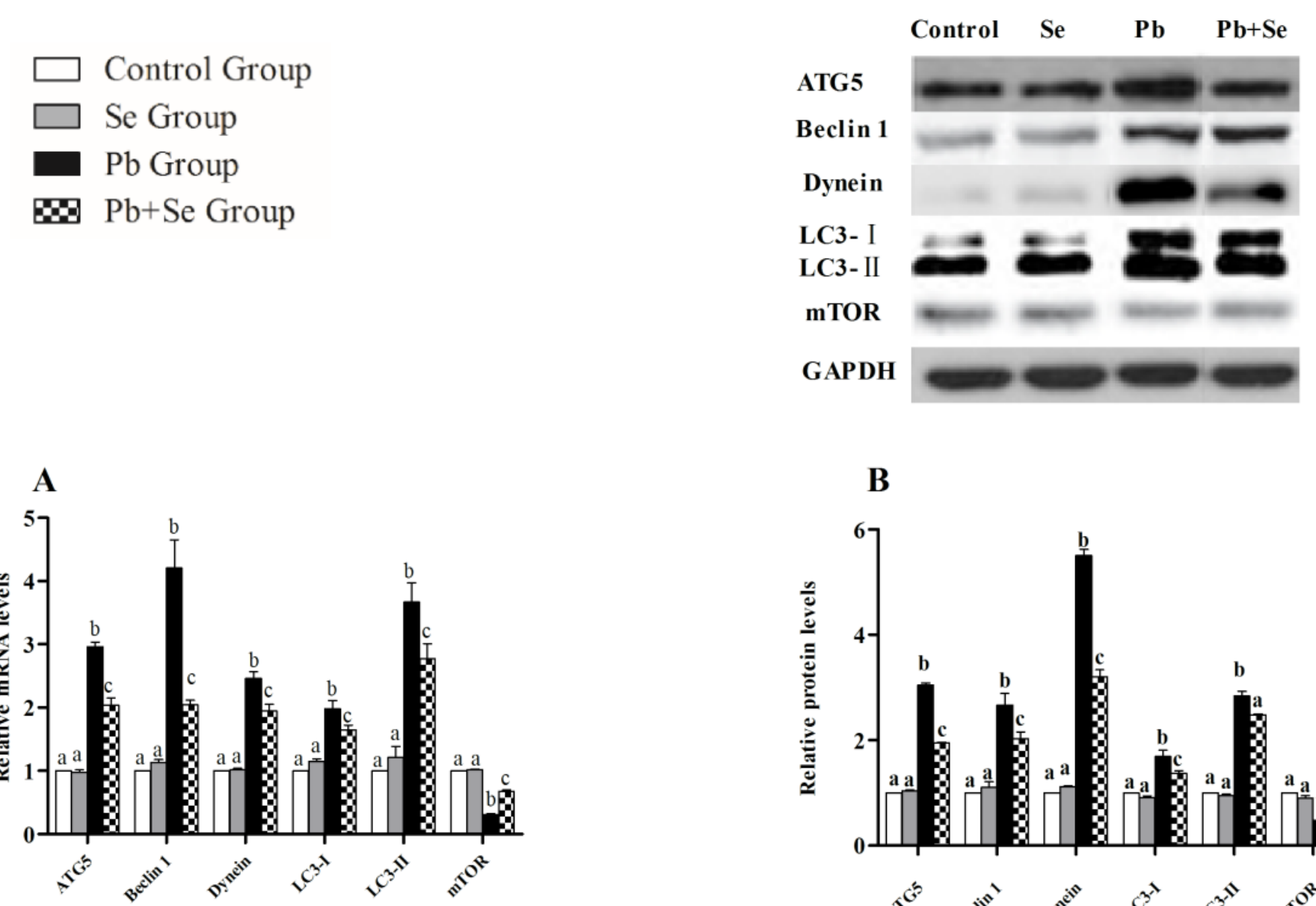

B

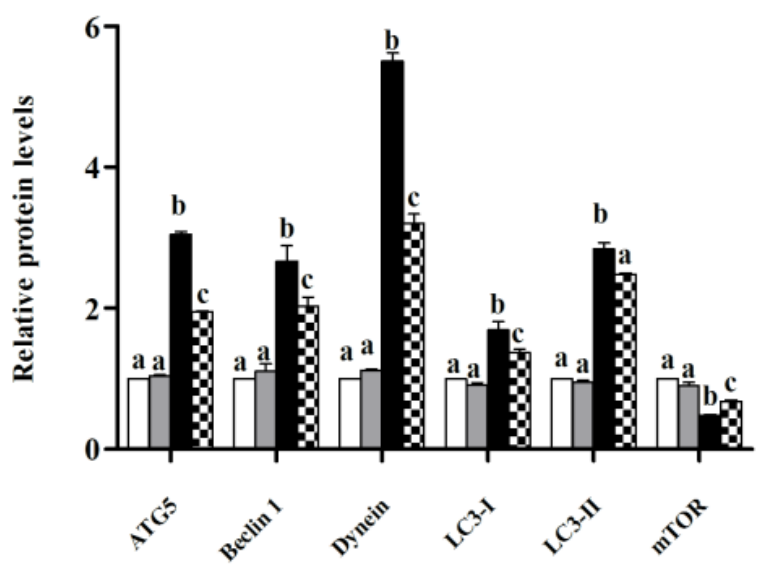

Figure 5

Effects of $\mathrm{Pb}, \mathrm{Se}$, and their co-treatment on mRNA and protein expression of autophagy-related genes in chicken kidneys on the 90th day. ATG5, Beclin 1, Dynein, LC3-区, LC3-区, and mTOR mRNA expression (A) were determined by real-time PCR and their protein expression (B) were determined using Western-blot. Bars represent mean $\pm S D(n=5 /$ group). Bars with different lowercase letters were significant different in different groups $(P<0.05)$. 